2014

\title{
Belonging to Law: Religious Difference, Secularism, and the Conditions of Civic Inclusion
}

Benjamin L. Berger

Osgoode Hall Law School of York University, bberger@osgoode.yorku.ca

Follow this and additional works at: http://digitalcommons.osgoode.yorku.ca/olsrps

\section{Recommended Citation}

Berger, Benjamin L., "Belonging to Law: Religious Difference, Secularism, and the Conditions of Civic Inclusion" (2014). Osgoode Legal Studies Research Paper Series. 58.

http://digitalcommons.osgoode.yorku.ca/olsrps/58 


\section{OSGOODE}

OSGOODE HALL LAW SCHOOL

YOR K U N I VERSITY

\section{OSGOODE HALL LAW SCHOOL}

LEGAL STUDIES RESEARCH PAPER SERIES

Research Paper No. 16/2014

Vol. 10, No. 5 (2014)

Belonging to Law: Religious Difference, Secularism, and the Conditions of Civic Inclusion

Working Paper

Benjamin L. Berger

\section{Editors:}

Peer Zumbansen (Osgoode Hall Law School, Toronto; Canada Research Chair in Transnational Economic Governance and Legal Theory - Editor in Chief)

Stephen Ji (Osgoode Hall Law School, Toronto - Production Editor) 
Osgoode Legal Studies Research Paper No. 16/2014

\author{
Vol. 10, No. 5 (2014) \\ Belonging to Law: Religious Difference, \\ Secularism, and the Conditions of Civic Inclusion \\ Working Paper
}

Benjamin L. Berger

\begin{abstract}
:
This paper examines the appeal to law as the basis for civic identity and political belonging under conditions of religious diversity. Beginning by assessing the descriptive utility of the concept of "secularism," the paper argues that secularism is best approached as a repertoire of moves available in negotiating the relationship between religion and political authority, focussing then on one such move evident in the contemporary project of liberal secularism: the assertion, in the face of the challenges posed by religious diversity, that to belong to the political community means, above all else, to belong to law. This shift of "obedience to the law" to the diagnostic centre of civic belonging is explored by turning to two case studies drawn from the legal encounter with Islam in Canada: the debate over official recognition of Sharia law and controversies surrounding the niqab. Having assessed the implications that this move has for the understanding and management of religious difference, the paper explains the attractiveness of this symbolic appeal to law - whereby law begins to stand as a kind of synecdoche for the secular state - and assesses the effect of this alignment of law and belonging on the politics of religious diversity.
\end{abstract}

\title{
Keywords:
}

Civic Belonging, Law, Religion, Secularism, Religious Freedom, Islam

\author{
Author(s): \\ Benjamin L. Berger \\ Associate Professor \\ Osgoode Hall Law School \\ York University, Toronto \\ E: bberger@osgoode.yorku.ca
}




\title{
BELONGING TO LAW: \\ Religious Difference, SECularisM, AND THE Conditions of Civic InCLUSION
}

\author{
Benjamin L. Berger*
}

Within the modern politics of liberal secularism, can law serve as the conceptual basis for civic identity and belonging?

A common way of imagining law is as technique. Law is a tool at the disposal of states and - for the more pluralistically ambitious - transnational and subnational communities to achieve functional ends. In this way of thinking about it - perhaps a "folk" understanding (Moore, 1978) - law belongs to us. Law is something that communities develop, that communities hold and deploy, and in this sense one can speak of law in the possessive: Canada's, England's, or France's legal system. But this is not the only way of imaging the lines of belonging between law and community. One thinks of Jewish law, in which a community is defined and constituted by its relation to law; Jews are those who belong to the Torah, who belong to law. In Canada, one cannot but think of Indigenous legal traditions, in which law is not created or deployed by communities as much as it is engaged with as a means to constitute and affirm communities. (Borrows, 2010) Nor is this sense of the configuration of law and belonging foreign to modern national political contexts. The imaginative heart of American republicanism is the idea of a community constituted under law, the Constitution being something that one could intelligibly claim to be defending, making law something for which one would fight and die (Kahn, 1997).

The political and social challenge of religious diversity is, in sizeable measure, a challenge of community self-definition. Religious difference makes patent the diversity that subsists behind the patinas of value convergence characteristic of too much modern nationalist politics. (Webber, 1994) Religious diversity is one fact that stirs us from the oneiric aspiration of a political community bound together by shared worldviews and lends urgency to the search for a common ground of community belonging. How is

\footnotetext{
* This piece benefitted greatly from conversation with Robert Hefner, Adam Seligman, the other participants in "Civic Enculturation and Citizenship in North America and Western Europe" conference held by the Institute on Culture, Religion, and World Affairs at Boston University in 2012. Thank you also to the two anonymous reviewers for their helpful suggestions, and to Hannah Askew, Geneviève Murray, and Samara Secter for their outstanding research assistance and their incisive comments on earlier drafts of this piece.
} 
a secular state - one committed, in some fashion, to the disentanglement of political authority and religious and metaphysical claims - to respond to deep religious difference while maintaining some workable sense of political community? The lessons of modern history, as well as the facts of transnational mobility and migration, preclude any straightforward or overt political self-definition on ethnic or racial lines. Common currencies, access to markets, and social welfare entitlements do not seem sufficiently robust to carry the weight of community belonging, as the European experiment seems to consistently show (See Haltern, 2003). But what about law? Met with the challenges of community definition occasioned by deep religious difference, should secular liberalism look to law as a candidate to sustain community belonging?

And so I return to the question of how to imagine the role of law in the modern politics of religious difference. In a liberal secular paradigm, does law belong to us, or do we belong to law?

To some, this question is flawed at its foundation because it assumes a mistaken premise: that there is one historical or sociological phenomenon called "secularism." In the past many years an important body of research has developed that emphasizes the broad range of political and legal configurations that subsist under the general mantle of secularism, a rich variety of secularisms that is obscured by reference to a single modern phenomenon. Jakobsen and Pelligrini (2008) urge a pluralization of the idea of the secular, offering a range of studies of the ways that religion and political power can be disentangled in various historical and social contexts. Ahmet Kuru's examination of secularism in France, Turkey, and the United States draws out the diverse methods and mechanisms used to give local shape to the secular in each national setting, emphasizing in particular the influence of political history and reactions to an ancien régime in the development of various approaches to realizing secularism (Kuru, 2009). These and other works have been insistent in their call to attend to the range of local approaches to decoupling religion and political authority and the diverse social, institutional, and legal dynamics involved in the "varieties of secularism" (See, e.g., Warner et al., 2010; Whitman, 2008). The forms of secularism are also made various in part by virtue of the political and emotional polysemy of religion itself: "[t]he ways in which the concept of 'religion' operates in [a] culture as motive and as effect, how it mutates, what it affords and obstructs, what memories it shelters or excludes, are not eternally fixed" (Asad, 2006: 106). "That," Asad insists, "is what makes varieties of secularism... always unique" (Asad, 2006: 106). It seems dangerously reductive to speak of what happens within "the modern politics 
of secularism" or what features characterize "secularism." Too much of interest and importance is elided when this diverse range of phenomena are assembled under a capacious umbrella of "the secular".

Yet there nevertheless seem to be a set of commonalities, linkages, and "family resemblances" between manifestations of the secular, shared or analogous features across these varieties of the secular that make it not only intelligible but also edifying to speak in broader terms. And so there is also something lost in an insistent focus on the particular. As one author aptly puts it, thinking of secularism only in local and particular terms presents the risk of underestimating "the globalizing power of the behaviors, knowledges, sensibilities, and political arrangements that have come to comprise the secular" (Fernando, 2010: 31). In a transnational and not yet entirely postcolonial era, political and legal common sense have a distinctive mobility, lending importance to the work of those who seek to identify patterns, trends, and attitudes that appear to adhere to the idea of the secular (See, e.g., Asad, 2003; Taylor, 2007). Certain experiences of the politics of secularism are common enough across local contexts, and deviations from these larger trends seem significant enough, that these broader brush-stroke analyses are also indispensible.

It seems, then, that we should seek to analyse the politics of secularism while somehow holding together the imperatives and insights of both the particular and the general. With this methodological challenge in mind, secularism is perhaps best approached as repertoire of moves available in the project of untethering religion and political authority. Local context, social and political history, and institutional structures will condition the moves that have particular purchase or appeal in a given national or regional tradition; certain tools will lie more readily at hand depending on these factors. Yet one can still intelligibly and usefully speak of certain possibilities and resources available by virtue of participation in something like a project of secularism, a project that is more or less recognizable as such across diverse local instantiations. Within that broader context, when facing particular social or political challenges, certain of these resources will present as attractive candidates for use; each will also carry their own risks and pathologies. The analysis of this repertoire - what makes certain moves appealing or troublesome and what social and political dynamics they engender - is one fruitful way into the study of secularism and the politics of religious difference.

This piece examines one such move, the political dynamics it generates, and the reasons for its appeal, within one social and historical context. I examine a particular response to the problem of community 
definition that has become evident in the Canadian politics of liberal secularism: the assertion, in the face of the challenges posed by religious diversity, that to belong to the political community means, above all else, to belong to law. Belonging, including to law, can involve a range of attitudes, habits, and postures. Rich forms of belonging are expressed not only through respect and identification, but also resistance and dissent. The particular claim for belonging at issue in this piece, however, is a narrower, less compromising form whereby submission to law (understood in a monistic and statist fashion) is what defines political community. The move at issue, then, is the migration of law to the symbolic heart of community belonging such that the normative citizen is defined by her submission to state law. In this increasingly invoked trope of legality, submission to law substitutes for the perplexity and challenges of community definition and negotiation across differences. In the modern Canadian politics of secularism, the liberal political force of the idea of the rule of law is being used to shift 'obedience to the law' to the diagnostic centre of civic belonging. But it is questionable whether law can satisfactorily sustain this role. Like other moves in the repertoire of secularism, this symbolic configuration of law and belonging has its pathologies and distorting effects. Among the various tools available in the politics of secularism, should we look to the law as the ground for civic inclusion?

The heart of this piece uses case studies drawn from Canada to explore the crucial place that this relationship between law and belonging is coming to play in the Canadian project of secular civic formation and the effects that this move has on the understanding and management of religious difference. The paper then examines why this kind of symbolic appeal to law is so attractive, enjoying such rhetorical force within liberal political culture, and assesses the effect of this alignment of law and belonging on the politics of religious diversity.

\section{Submitting to law and civic identity in Canada}

Issues of national identity in Canada have been tethered to questions of religious belonging and law since the formal origins of the country with the Treaty of Paris, 1763, which recognized that the country's political and legal character would be defined by the co-existence of English Protestant and French Catholic communities. With its foundations in the constitutional protection of French Catholic and English Protestant schooling, and moving through a history of religious diversification and, in the 1970s, the official adoption of a policy of multiculturalism, the Canadian experience of the 
interaction of religious difference, politics, and law is distinctive and rich. The state's troubled historical engagement with Aboriginal communities and the need to reckon with the contemporary constitutional protection of Aboriginal rights in s. 35 of the Constitution Act, 1982 and the continued salience of Aboriginal legal traditions has drawn out further dimensions of this complex imbrication of law, sovereignty, cultural worldview, and community belonging. The "complicated emotional inheritances" (Asad, 2006: 102) produced by this local history has meant that secularism has taken unique shape in Canada - eschewing strict non-establishment and formal laïcité while recognizing constitutional protections for religious freedom - and that the lines between law and community belonging have been particularly live and salient.

Within that frame, contemporary debates about religious difference and secularism have focussed on questions surrounding a range of issues including gender equality, state education, sexual orientation, religious accommodation, and public religious symbols, and have involved many religious and cultural communities. Yet, as in other Western liberal democracies, the Muslim community in Canada has occupied a central role in the modern politics of religious difference, in debates about the meaning of secularism, and in the definition of the boundaries of political belonging. ${ }^{1}$ For this reason, despite a fascinating range of historical and contemporary cases that raise issues of the interaction of law, politics, and religion, this paper focuses on two high profile and recent controversies involving Muslim communities in Canada.

\section{The 'sharia law debate'}

The symbolic role of state law came to the forefront of Canadian debates about religious diversity through the much-publicized "sharia law debate." This political and legal controversy arose in the Province of Ontario in the late fall of 2003 when an organization called the Islamic Institute of Civil Justice proposed the use of arbitration tribunals that would resolve civil matters, particularly family law and inheritance disputes, through the application of Islamic law. (Bakht, 2004) Since the early 1990s, the Ontario Arbitration Act had allowed for the private arbitration of civil disputes using agreed-upon principles or systems of law. (Boyd, 2004) Although religious

\footnotetext{
${ }^{1}$ On the role of Islam in shaping contemporary conceptions of, debates about, and politics surrounding secularism see, for example, Asad (2003), Scott (2007), Hurd (2008), and Modood (2012).
} 
arbitration, in the form of Jewish beis din and among some Christian and Ismaili groups, had been taking place for many years on the strength of this legal framework, this proposal from the IICJ created something of a "moral panic" (Razak, 2007: 7) that became the focal point for debates about the boundaries of religious freedom in Canadian society. Substantial concern was voiced by feminist organizations, who argued that the use of Sharia in settling family disputes would have particular and particularly devastating effect on women. The Canadian Council of Muslim Women, the Women's Legal Education and Action Fund (L.E.A.F.), the National Council of Women and the Law (N.A.W.L.) and a number of other organizations expressed powerful critiques of the use of religious law to settle civil disputes. The media fed a general alarm, with one newspaper declaring "Muslim barbarians [were] knocking on the gates of Ontario". (Bakht, 2006: 70) As Razak recounts, newspapers warned Canadians that, with this proposal, "they were on the brink of their own fateful encounter between Islam and the West, a swift descent from the ideals of the British Empire to a barbaric multicultural present". (Razak, 2007: 9)²

Subject to this substantial public pressure, the Government of Ontario commissioned a report into the use of private arbitration to resolve family law disputes, to be written by former Attorney General of the Province, and feminist activist, Marion Boyd. A number of proposals circulated in the public debate. Although the controversy had been inaugurated by the prospect of Islamic arbitration, and although much of the rhetoric was directed at Muslim communities in Canada, the political and legal difficulties associated with singling out Sharia led to many suggesting that all faith-based arbitration in family law matters should be banned. Others went further, suggesting that private arbitration of all forms should be prohibited in family law matters, as it was in Quebec. After study and consultation, Boyd's report recommended that, with the addition of certain new oversight measures and education initiatives, religious arbitration continue to be permitted in Ontario. (Boyd, 2004) Initially the government appeared to endorse this conclusion, declining to act against Islamic arbitration. After sustained public furore, however, the Government reversed course. On September 11, 2005, the Ontario Government announced that it would ensure that there was "one law for all", ultimately introducing The Family Statue Law Amendment Act, 2006. This legislation purported to ban all faith-based

\footnotetext{
${ }^{2}$ For an extensive study of the media coverage in Canada surrounding the "Sharia Debate", with particular attention to the representation of Muslim women's agency, see Anna Korteweg's article on this episode in the Canadian politics of religious difference (Korteweg, 2008).
} 
arbitration by establishing that all family law arbitrations in the province would be "conducted exclusively in accordance with the law of Ontario or another Canadian jurisdiction." 3

Sherene Razak has explored the ways in which the so-called "Sharia debate" rehearsed the "eternal triangle of the imperilled Muslim woman, the dangerous Muslim man and the civilized European". (Razak, 2007: 5) Others have shown the way in which, despite legitimate concerns about the negative impacts of traditional religious law on women, feminist resistance to faithbased arbitration often depended on the opposition of religion and choice, framing the figure of the religious woman in an uncomfortably categorical position of disempowerment or even definitional self-estrangement. (Bakht, 2006; Razak, 2007) As Anna Korteweg argues, rather than examining the relationship between religion and agency, the public discourse on this issue "questioned Muslim immigrant women's capacity to act in a self-interested way." (Korteweg, 2008: 437) The "Sharia debate" holds out much of interest in an analysis of the interactions of law, religion, politics, and gender. ${ }^{4}$ of particular interest to this paper is the symbolic role played by law in this instance of the management of religious difference and the construction of civic identity.

Prior to these amendments, the legal framework of private arbitration was one in which multiple normative orders were recognized and afforded space. When this formal pluralism was met with deep anxieties about religious and cultural diversity the law took on a role as the overriding marker for community identity. Membership in the demos was to be marked by the law to which we all belong. This role for state law involved two moves: Islamic (ultimately, all religious) law was denatured as "law," precluded from the order of publicly salient norms, while a simultaneous claim was made that legal belonging is the defining feature of the political community. Premier McGuinty claimed that to allow faith-based arbitration would "threaten our common ground" (Bakht, 2006: 80) as a political community; this common ground would be secured by confirming that all would have to conform to secular law. Subject to this symbolic role for law, the normative aspect of religion is flattened, suppressed, in favor of state law, which takes on special salience as the basis of belonging in political community.

\footnotetext{
${ }^{3}$ This limitation was inserted into both the Arbitration Act, 1992, s. 2.2, and the Family Law Act, s. 59.2 .

${ }^{4}$ Anna Korteweg and Jennifer Selby's edited volume on Islam, Sharia, and family arbitration offers a wonderful exploration of these dimensions of the issue (Korteweg and Selby, 2012).
} 
Religious legal orders are not actually extinguished by such a move, of course, nor is state law able to occupy the entire field of the normative in the lives of the governed. Religious law persists as a social fact. Indeed, the amendments brought about by the Sharia debate did not prohibit religious arbitration. (Bakht, 2006) Individuals could continue to resolve issues based on whatever law they saw fit; the most that the legislation could do was to simply deny state-backing - the enforcing power of the state - to agreements reached on the basis of faith-based arbitration. Yet what persists as a social fact is denied public salience as part of the normative world. That suppression is the essence of the "jurispathic" move, the pluralism repressing aspect of state law that Cover identified so well as a feature of the adjudicative moment (Cover, 1983). At these jurispathic points, other nomoi suffer a public death, not an extinguishment.

Razak argues that those who intervened publicly to condemn the use of faith-based arbitration did so in a way that tended to underwrite the modern/premodern divide between secularism and religion, another way of defining the boundaries of community. But the law played a crucial symbolic role in even this potent distinction: to belong to the modern is to belong to secular law, not to religion or a religious normative order. In a turn of notable philosophic and political irony, this symbolism operated by aligning freedom with law. Divergent models of Muslim women's agency were at stake in the debates surrounding Sharia in Ontario; as Korteweg demonstrates, the dominant model framed women's agency "as contingent upon... resistance to Islam" rather than "as embedded in religious (and other) contexts." (Korteweg, 2008: 435) With (premodern) religion as a constraint on agency, state law would be the means of securing freedom for religious women. Rather than one of the contexts, alongside religion, in which agency is embedded, law is the condition for freedom. Submission to law will make you free (and modern). Of course, the boundaries set up by this demand for collective submission to state law are not just these kinds of grand epochal and philosophical distinctions - they are more political and local. Law is marking a specific community, is standing in for that community's identity, and serving as that which binds the community together. It is not just "one law for all", it is "one law for all of us". In this, the imaginative role of law in this configuration of the politics of civic enculturation is manifest. This is the logic and political dynamic engendered by the alignment of law and belonging. To be part of the community requires submission to the law. One becomes a normative citizen by showing obedience to the law. 


\section{The niqab and identity through law}

The veiled Muslim woman has been, ironically, the focal point for much debate about the nature of the secular state and the management of religious difference. Perhaps best known has been the debate in France following the Stasi Commission of 2003, culminating in a law that prohibited "conspicuous religious symbols" in public schools. Much analytic attention was given to this "Islamic Veil Affair" as an example not only of the distinctive French form of secularism, laïcité, but of the European hostility toward Islam. For Talal Asad, this debate in France was an example of the state engaged in symbolic work, exercising its authority to define the meaning of a sign and then to consolidate its authority in reaction to these meanings. (Asad, 2006) Asad notes that it was not, ultimately, the veil itself that provoked state concern; rather, it was the act of displaying the veil, the will to display the symbol, that troubled the secular society. (Asad, 2006: 97) On this view, the threatening significance of the religious symbol inheres in its reflection of a desire to assert particular identity, religious identity, in a manner inconsistent with the universal character of republican legal identity. ${ }^{5}$ The force of religious belonging is politically constructed as a constraint on or distortion of autonomy, the remedy to which is, paradoxically, to be found in yielding to the liberal republican state. The symbolic work of the state is carried out in cultivation of "particular sensibilities essential to a particular kind of contradictory individual - one who is morally sovereign and yet obedient to the laws of the secular republic, flexible and tolerant yet fiercely principled." (Asad, 2006: 104)

The niqab has similarly moved to the centre of the public debate surrounding religious difference and civic identity in Canada. In early 2010 the Liberal Government of Quebec tabled Bill 94, which would prohibit anyone employed by the government to deliver a service and anyone accessing government services from doing so while wearing a face covering. This legislation was introduced following a pitched debate that arose after a niqab-wearing woman was expelled from French language classes because she refused to remove her face covering. As it was in France, this legal move was tethered to a conception of secularism, Premier Charest explaining that the Bill was a reflection of Quebec's commitment to "open secularism". With

\footnotetext{
${ }^{5}$ John Bowen importantly shows that despite the political and rhetorical force of this public ideal of all citizens interacting with a French republican identity, unmediated by other associational allegiances, a rich associational life in fact subsists beneath this politics of common public identity (Bowen, 2010).
} 
this phrase Premier Charest was invoking a concept advocated by Charles Taylor and Gérard Bouchard in Quebec's own public commission into religious difference, the Bouchard-Taylor commission. (Bouchard and Taylor, 2008) But Bill 94 was also represented to the public as an emblem of the demands associated with civic enculturation, a rather narrow legal measure with grand symbolic aspiration, standing compendiously for what it meant to be part of Quebec society. Quebec Immigration Minister Yolande James explained what lay at the heart of the Bill: "If you want to integrate into Quebec Society, here are our values. We want to see your face." (Hamilton, 2010) This story continued when, in 2013, the governing Parti Quebecois proposed a "Charter of Quebec Values," the most contentious aspect of which was to prohibit, in the name of secularism, those serving in public roles from wearing conspicuous religious symbols. ${ }^{6}$ Although the ban would capture all religious symbols, including kippahs and turbans, the niqab and hijab were very much at the centre of contemplation.

This link between the issue of wearing the niqab and questions of civic identity was made explicit when, in 2011, then Federal Minister of Citizenship and Immigration, Jason Kenney, announced that women would not be permitted to wear the niqab while taking the oath at citizenship ceremonies. According to Minister Kenney, "[a]llowing a group to hide their faces while they are becoming members of our community is counter to Canada's commitment to openness, equality and social cohesion." (National Post, 2011) Although it seemed that no formal steps were routinely taken at immigration ceremonies to ensure that all new citizens were actually saying the oath, the display of one's face nevertheless took on particular symbolic import aligned with inclusion in the national community. Indeed, Minister Kenney would later explain that, apart from any difficulty in verifying that individuals were actually saying the oath, his concern was the public and legal nature of the activity: "It's a public licensing, a declaration of your membership in the community and you do that in front of your fellow citizens in public. To obscure yourself at that essentially public moment when you're making a legal undertaking in front of your fellow citizens undermines the nature of the public oath." (Globe and Mail, 2012) The immigration ceremony is the most literal moment of citizen formation

\footnotetext{
${ }^{6}$ The Parti Québecois sought to put this proposed bill (Bill 60) at the heart of a provincial election called for the spring of 2014. The election turned out to focus, instead, on economic issues and questions of provincial sovereignty. The PQ were soundly defeated in the election, held on April 7, placing Bill 60 on the political backburner, for the time being. For discussion of Bill 60 see the backgrounder and collection of comments on The Immanent Frame: http://blogs.ssrc.org/tif/2014/02/20/the-charter-of-quebec-values/.
} 
through law - it is the formal acceptance of a new civic identity, of belonging to a new political community. Among the many manifestations of difference tolerated at that moment, wearing the niqab could not be one. This symbol was simply too saturated with the will to manifest a different identity, a symbol felt to be in tension with belonging to the secular state.

In the courts, the most recent development in the controversies surrounding the niqab is the case of R. v. N.S. N.S. was the complainant in a case involving allegations of repeated sexual assault by her uncle and her cousin while she was a child. She wore a niqab. During the preliminary inquiry the accused sought an order that would require N.S. to remove her niqab when she testified. The accused's principal argument was that N.S.'s niqab denied the accused proper cross-examination of the complainant, interfered with the assessment of her credibility, and thereby eroded the ability of the accused to make full answer and defence. The Crown and, ultimately, counsel for N.S. strongly objected, citing her Charter rights to religious freedom as a shield against such an order. The preliminary inquiry judge balanced the right of the accused to full answer and defence against the complainant's religious practices, ultimately ordering her to remove the face covering. N.S. moved to quash this order and the issue moved up through the system to the Ontario Court of Appeal and, ultimately, to the Supreme Court of Canada, where a majority of the court held that the proper approach was, indeed, to balance the competing rights at issue, but sent the matter back to be reconsidered in light of the Court's guidance. On re-examination, the preliminary inquiry judge again ordered that N.S. remove her niqab. The case engendered pitched public debate about the limits of religious diversity and the legitimate demands that the state can place upon its citizens irrespective or in spite of religious difference.

All of these Canadian controversies are instances in which, faced with deep normative difference, obedience to the law came to serve as a diagnostic for civic inclusion. Bill 94 and the proposed Charter would create a legal rule, obedience to which is a condition of full inclusion in Quebec's society. The citizenship ceremony is an explicit act of submission to sovereignty and, under Minister Kenney's rules, demands divestment of this expression of religious identity. But I wish to focus on the final example, the issue of testifying with the niqab, as an illustration of the use of this move in the repertoire of secularism - the claim that in a secular state, one must first belong to law.

Law is not just a regime of substantive rules, it is a world of procedure and performance; to draw from Seligman, et al., law is a form of ritual, a subjunctive activity that creates a shared social world around an imagined 
"as if". (Seligman et al., 2008) The courtroom holds a special place in the symbolic architecture of the modern rule of law. The mythology of the courtroom holds that it is the place in which truth is discerned, where the claims of state power are tested against the higher authority of law, where disputes between individuals are settled by resort to the immanent justice of the law. Paul Kahn has argued that in a constitutional democracy the judge acts as the high priest of the law, mediating between the interests before them and the law as an expression of higher will, of the constituent power of the demos. (Kahn, 2004) The courtroom is like the Delphic oracle of the modern secular state. And like the oracle at Delphi, one cannot disentangle the forms and rituals of engagement from the substantive ends of the courtroom. The courtroom is one important site for the performance of commitment to the law. This is not merely to indulge a rhetorical flourish. The symbolic paraphernalia of the court, from the formalities of dress and address to the architecture of the room, impress themselves upon the unfamiliar as overtly ritualistic - even church-like - in nature. The trial has important functional ends, not least of which is the attempt to arrive at truth. But to participate in a trial is also to take part in a ritual that sanctifies the authority of law as the expression of the will and values of the community. As one of the sets of reasons in the N.S. case put it, the courts and the trial process are understood as central to "the complex web of institutions, rules and values embraced by the notion of the rule of law, of a state and a society living under and within the law." (para. 74) ${ }^{7}$

Cast in this light, the debate about wearing the niqab while testifying says something important about the symbolic function of law in the management of religious diversity. To be sure, there is a pragmatic balancing taking place here. The loss of the opportunity to observe the face of the witness is a deviation from the conventional structure and assumed virtues of cross-examination. ${ }^{8}$ The witness also has privacy and equality concerns,

\footnotetext{
${ }^{7}$ Unlike Chief Justice McLachlin's majority reasons, which emphasized the need for a case-bycase balancing, Justice LeBel (Rothstein J concurring) would have held that the nature of the trial process and open courts dictate that a witness should never be permitted to wear a niqab while testifying. The difference in reasoning might be misleading, however. Given the details of the guidance given the majority on how to conduct this balancing, it seems clear that whenever the witness is offering important information on a contested point, the practical outcome will be the same as Justice LeBel's. For a discussion and critique of the legal analysis reflected in the majority decision, see Moon (2014: 101-105).

${ }^{8}$ Whether demeanor evidence is as reliable as is tacitly assumed in the conventions of trial procedure and the law of evidence is a crucial empirical point. In N.S., the Court felt that it had not been given enough social science evidence to disturb these structural and historical assumptions. For discussions of the value and use of demeanor evidence in criminal trials, see
} 
particularly in the context of alleged sexual assaults. The Supreme Court of Canada's majority judgment focussed on the nature of this balancing and how to approach it on a case-by-case basis. But the debate is also about the ultimate authority of legal ways and practices prevailing over alternative claims of authoritative belonging. The demands of obedience to legal process are as potent as the claim for obedience to substantive law. Whatever the pragmatic imperatives involved, if N.S. is ultimately told to remove her niqab, she is told that her participation in the collective project of law requires, first, that she submit to the ritual forms of law. Justice Abella was most sensitive to this point in her dissenting reasons, explaining that to require a witness to remove the niqab was tantamount to asking her "to choose between her religious beliefs and her ability to participate in the justice system." (para. 94) ${ }^{9}$ She must submit to legal process in order to belong to the justiceseeking community.

The niqab debates also reveal a facet of the internal machinery by which law secures its authority. Scholarly, juridical, and public debate often appeals to the idea that the niqab is not really "religious" in character but, instead, cultural. In this characterization one should hear again the ring of Cover's concept of the "jurispathic" (Cover, 1983). As Cover explained so well, in a pluralistic world the central challenge of adjudication is not the absence of law or even unclear law but, instead, too much law. In the adjudicative effort to thin this normative garden, assigning a norm to the realm of culture rather than religious imperative is one way to deny it a lawlike character. If a practice is required, commanded by religion, the competition of normative systems is much more fraught and visible. If what we have on our hands is not normative competition but, instead, law encountering "mere culture", the violence of state law is, itself, veiled. This dubious sorting into "command" or "culture" is an instance of the denaturing of religious law, a technique by which secular culture elides the normative messiness of religious diversity.

The preliminary inquiry judge in the N.S. case, who first ruled on the issue, unwittingly offered an evocative signal of the role of submission to legal ritual in the definition of civic identity. In deciding that N.S. would be ordered to remove her niqab, the judge observed that she was willing to uncover her face when she participated in the hajj, the pilgrimage to Mecca

Bakht (2012) and Laird (2014). Among the works of social science casting doubt on the reliability of demeanor evidence is Ekman and Sullivan (1991).

${ }^{9}$ Justice Abella would have preferred a general rule allowing the niqab unless the witness' face was somehow directly relevant to the trial. 
that is one of the pillars of Islam. To the judge, this was evidence that her felt obligation to wear the niqab was mutable should circumstances warrant. But the unspoken analogy is poignant. The hajj is a ritual performance of submission to God and of belonging to a community within Islam. The tacit equivalency drawn by the judge betrays the symbolic significance of participation in the rituals of law. The implied assertion is that the court the law - should occupy a similarly sacred position in the life of the normative subject. Through adherence to legal ritual one affirms the sovereignty of law and, with this, one's belonging to the civic community, which is as much constituted by the ties of law (Latour, 2010) as it is the author of law.

In his examination of the "Islamic veil affair" in France, Asad comes to an illuminating conclusion about the nature of French secularism. Laïcité, Asad explains,

is a continuous attempt by the state apparatuses at encouraging subjects to make and recognize themselves through appropriate signs as properly secularsized citizens who 'know that they belong to France'. (Only to France? Ultimately to France? Mainly to France?) Like other modes of secularism, laïcité is a modern form of political rule that seeks to define a particular kind of secular subject (whether "religious" or not) who can take part in the game of symbols the right kind of conventional signs - to demonstrate his or her loyalty to the state. (Asad, 2006: 106)

Law is a key player in this game of symbols. In the logic that circulates in public controversies surrounding the niqab in Canada, the normative subject manifests political belonging through submission to law, including legal ritual, procedures, and traditions. In this expression of the contemporary politics of secularism - according to this move in the repertoire of secularism - one belongs to Canada by belonging to law.

\section{The appeal and the violence of submission to law}

Having explored some of the social and political dynamics involved when submission to law becomes a marker for civic inclusion, I want now to consider why it is that law might come to occupy this potent symbolic position in the management of religious diversity. What makes the

invocation of law and legality such an attractive move in service of liberal 
secularism? Exploring this question requires reckoning with the ideological force of the rule of law.

Liberal political culture is virtually defined by its anxiety about engaging difference in terms of overarching narratives. It is, of course, liberally axiomatic that the state has no standing in questions of belief, no warrant to intervene in matters of worldview. But the anxiety around engaging in such issues goes deeper than this. In his book Putting Liberalism in its Place, Paul Kahn describes the problem of cultural pluralism as our age's "point of access into ethical and political deliberation." (Kahn, 2005: 1) In describing the broad differences in values with which cultural pluralism confronts us, he identifies a central anxiety that afflicts liberal political culture, the anxiety of being caught between the universal and the particular: "We worry about moral cowardice when we fail to respond critically, and about cultural imperialism when we do respond." (Kahn, 2005: 1) To this one must add the anxiety that liberal political culture lacks the resources to defend a position about metaphysics, ontology, or belief. It is, after all, precisely this set of positions that liberalism asks us to bracket when we exercise political authority. ${ }^{10}$ Met with claims of justice that reason from metaphysics, how is the liberal state to respond? And so there is a sense that George Grant has described as "the terrifying darkness which has fallen upon modern justice" (Grant, 1998 [1974]: 86): the felt inability to underwrite public norms with a deeper account of metaphysics or ontology.

The demand for obedience to law provides escape from these anxieties. It is a move that avoids the precarious terrain of community narratives and informing worldviews, engaging instead on the firmer footing of legality. Importantly, this move is underwritten by the substantial ideological force of the concept of rule of law. In its classic Diceyan formulation, the rule of law involves above all else the idea that no one is outside of or beyond the law. This conception of legality, which is "the distinctive modality of law" according to influential currents in contemporary jurisprudence (Lacey, 2003: 15), is taken to be the signal feature of democratic governance, a marker of modernity. "One law for all" has such resonance precisely because it evokes commitment to this fundamental tenet of the rule of law. In a liberal political culture there is an ideological and rhetorical resource in the invocation of legality that simply does not exist in the field of metaphysics, belief, and worldview. One can,

\footnotetext{
${ }^{10}$ Whether one draws the line at public reasoning, as Rawls did in his early positions, or in the institutional phase of decision-making, like Habermas, the stakes of the line drawing exercise are the same: managing the separation of worldview and political power.
} 
thus, demand submission to law where the demand for submission to culture or to worldview would seem tyrannical. This is the appeal of having law serve the key symbolic role that I have tracked in this piece. With the ideological force of the rule of law in support, resort to law as a marker of belonging provides a more comfortable basis for making a claim about social cohesion and the conditions of inclusion. Rather than overtly insisting on convergence in belief or value, the claim becomes simply that you must be legal, and the legitimacy of this demand is a function of the rule of law, not the culture of the community. In a context of dizzying diversity and a sense of vulnerability within public culture, resort to the law as the ground of belonging has a seductively simplifying, stabilizing feel.

To state it otherwise, in this configuration of law and civic belonging, the claim for submission to law serves as a device of depoliticization. ${ }^{11}$ In Regulating Aversion, Wendy Brown describes depoliticization as "removing a political phenomenon from comprehension of its historical emergence and from a recognition of the powers that produce and contour it." (Brown, 2006: 15) As I have explained, in liberal political culture, the concept of the "rule of law" enjoys conceptual autonomy from the realm of culture or politics. Brown puts it as follows: "secularism, the rule of law, equal rights, moral autonomy, individual liberty. If these principles are universal, then they are not matters of culture, which is identified today with the particular, local, and provincial." (Brown, 2006: 21) Rule of law is simply a feature of the modern state, a natural element of democratic governance.

To employ submission to law as the marker for civic belonging is, thus, a move that seeks to extract the phenomenon of civic enculturation from its political and historical contours. Rather than engaging in debate on differences in value, differences in understanding the role of self-making and autonomous choice in the good life, rather than subjecting public norms to the vulnerability of open contestation or defending the supremacy of one normative world over others, one can appeal to the universality and givenness of the rule of law. In the case of the Sharia arbitration debate in

\footnotetext{
${ }^{11}$ Although my focus is on the liberal culture of law's rule, my argument here is sympathetic to Nicola Lacey's criticism of the tendency in contemporary jurisprudence to separate concepts of law from the social, political, and institutional conditions in which those concepts emerge. In particular, Lacey is critical of the overconfidence evident in much contemporary analytic jurisprudence about the universality and conceptual autonomy of the modal qualities (like legality) associated with the rule of law. As Lacey explains, "[a]t a sufficiently high level of abstraction, we can of course produce some conceptions of 'law' or 'legality' which are more widely applicable. But we do so at some cost" (Lacey, 2003: 15). One of those costs, I suggest, is the concealment of the historical and political dimensions of social phenomena.
} 
Ontario, the complicated issue of what deep religious difference in a multicultural society might imply for legal pluralism is suppressed in favor of the demand for a single secular state bound together by a common law. When it comes to the niqab in the courtroom, the question of how our historically dynamic and socially responsive trial practices might accommodate religious difference blanches in light of the demand to conform, like all citizens, to legal process. In place of the messiness of community definition and the challenges of civic enculturation in a religiously diverse society, law offers a symbolic tool of apparent solidity, clarity, and neutrality; moreover, at the same time that it marks civic inclusion and defines the good citizen, this demand to declare that one belongs to law also consolidates the authority of the secular state. Submission to law thus becomes a singularly appealing trope in the project of liberal secularism.

Though seductive, the invocation of law as the ground of civic belonging ultimately fails in its project of depoliticization. The hope, as I have described it, is that by defining civic belonging as belonging to law, one can bypass the fraught cultural dimensions of civic enculturation in the context of religious diversity. Law serves as a symbolic shortcut around the more challenging terrain of metaphysical and ontological difference. But the success of this technique depends upon two reductions. Law must be denatured as a cultural artefact, while religion is denatured as a source of normative obligation. Only with these "flattenings" in place can the conceit of pacification subsist. Both make good sense within liberal political culture, in which law enjoys a myth of neutrality - a neutrality that makes it the possible public meeting ground for a range of religious and cultural views - and religion is confidently assigned to the private realm of preference, habit, and culture. In essence, the private/public distinction so important to liberalism makes plausible the claim that law can serve as the basis for social cohesion.

Outside the conceits of liberal political culture the idea of belonging to law looks very different, indeed. If one takes seriously the link between belief and conduct, religion resists the confines of private sphere and makes normative demands on public conduct. Equally, the thickly cultural nature of the rule of law becomes apparent as one sees it as a distinctive way of imagining the world, a contingent expression of a particular political and even religious history, a way of conceiving of time, space, authority, and of what is of ultimate value in the human subject. (Berger, 2008; Kahn, 1999) Indeed, the very way in which law imagines religion is an artefact of its liberal cultural commitments (See Berger, 2007). However justified such a demand might ultimately be in a liberal democracy, the demand for obedience to state law can denude religious belonging of its normative 
implications. Equally, to submit to law is to yield to a thick cultural narrative. For communities of deep religious difference, this is the cultural violence that subsists beneath the liberally appealing demand that, in a secular society, we must all belong to law. It is this experience of submission to law for those who are not already committed to the project of liberal secularism that means that the aspiration of depoliticization will never entirely succeed. It is not so easy to belong to law.

\section{Conclusion: law, secularism, and synecdoche}

One available move within the politics and patterns of secularism is the migration of law into a potent metaphorical position, whereby law begins to stand as a kind of synecdoche for the secular state. Within a context of deep religious diversity, submission to law serves as a diagnostic marker of civic belonging and of the due enculturation demanded of the good citizen. With this, law stands in to define a much more complex whole of which it is but a part - political community. Contemporary Canadian debates about religious difference and civic inclusion show how this role for law may arise, as well as the social and political dynamics that it sets in motion. At a time at which the possibility for productive engagement across divergent narratives seems daunting, when the community's self-understanding is subject to intense contestation, law has assumed this metaphorical role in which submission to law comes to represent community belonging. In the context of disputes about the limits of toleration and accommodation in a multicultural but secular society, adherence to law offers itself as comforting evidence of the acceptance of a particular (and culturally, historically specific) configuration of the public and private, respect for the assignation of religion to the private realm, and an acknowledgement of rational autonomy as a condition of liberty. And so, bypassing the normative complexity of diversity, we increasingly lean on the ideological force of the rule of law and demand instead, simply, that you belong to law.

The impulse to adopt this role for law must be understood as part of the search for the ties that will bind in a society characterized by deep diversity. Finding such points of common ground is no doubt imperative and the search is not just essential, but the ethical foundation of living within cultural diversity. There are risks, however, in looking to law as the basis for these ties. One worries that such reliance on law consolidates authority in too narrow a group of social actors. Furthermore, reliance on the synecdoche of law leaves too little room for normative difference; it denies the legal pluralism that is a fact of our modern existences and reifies law in 
an unduly monolithic, statist, and exclusive form, depriving us of the normative biodiversity that is one of the most attractive features of multiculturalism. Moreover, the form of political belonging imagined through this insistence on submission to law is an impoverished one, bereft of the richness brought through contestation and resistance. Yet the principal risk is that this resort to law will simply be too successful in obscuring the political dimensions - the violence, history, power - involved in the definition of civic community. It is too easy, under the conceits of secular law, to lose track of the winners and losers of social inclusion.

\section{Cases Cited}

R. v. N.S., 2012 SCC 72.

\section{References}

Asad T. (2003) Formations of the Secular: Christianity, Islam, Modernity, Stanford, Calif.: Stanford University Press.

Asad T. (2006) French Secularism and the 'Islamic Veil Affair'. The Hegehog Review: 93-106.

Bakht N. (2004) Family Law Arbitration Using Sharia Law: Examining Ontario's Arbitration Act and its Impact on Women. Muslim World Journal of Human Rights 1.

Bakht N. (2006) Were Muslim Barbarians Really Knocking on the Gates of Ontario?: The Religious Arbitration Controversy-Another Perspective. Ottawa L. Rev. 40th Anniv.: 67.

Bakht N. (2012) What's in a Face? Demeanour Evidence in the Sexual Assault Context. In: Sheehy EA (ed) Sexual Assault in Canada: Law, Legal Practice and Women's Activism. Ottawa: University of Ottawa Press, 591612.

Berger BL. (2007) Law's Religion: Rendering Culture. Osgoode Hall L.J. 45: 277-314.

Berger BL. (2008) The Cultural Limits of Legal Tolerance. Can. J. L. \& Jur. 21: 245-277.

Borrows J. (2010) Drawing Out Law: A Spirit's Guide, Toronto: University of Toronto Press. 
Bouchard G and Taylor C. (2008) Building the future, a time for reconciliation: report, [Québec]: Commission de consultation sur les pratiques d'accomodement reliées aux différences culturelles.

Boyd M. (2004) Dispute Resolution in Family Law: Protecting Choice, Promoting Inclusion.

Brown W. (2006) Regulating Aversion: Tolerance in the Age of Identity and Empire, Princeton and Oxford: Princeton University Press.

Cover RM. (1983) The Supreme Court 1982 Term -- Foreword: Nomos and Narrative. Harv. L. Rev. 97: 4.

Ekman P and O'Sullivan M. (1991) Who Can Catch a Liar? American Psychologist 46: 913.

Fernando ML. (2010) Reconfiguring Freedom: Muslim Piety and the Limits of Secular Law and Public Discourse in France. American Ethnologist 37: 19-35.

Globe and Mail. (2012) Kenney on transformational changes to immigration model. The Globe and Mail.

Grant G. (1998 [1974]) English-Speaking Justice, Toronto: House of Anansi Press. Haltern U. (2003) Pathos and Patina: The Failure and Promise of Constitutionalism in the European Imagination. European Law Journal 9: $14-44$.

Hamilton G. (2010) Quebec bill would ban niqabs to all receiving government services. The National Post.

Hurd ES. (2008) The Politics of Secularism in International Relations, Princeton, NJ: Princeton University Press.

Jakobsen JR and Pellegrini A. (2008) Secularisms. Durham and London: Duke University Press.

Kahn P. (2004) The Question of Sovereignty. Stan. J. Int'l L. 40: 259-282.

Kahn PW. (1997) The Reign of Law: Marbury v. Madison and the Construction of America, New Haven and London: Yale University Press.

Kahn PW. (1999) The Cultural Study of Law: Reconstructing Legal Scholarship, Chicago and London: University of Chicago Press.

Kahn PW. (2005) Putting Liberalism in its Place, Princeton: Princeton University Press.

Korteweg AC. (2008) The Sharia Debate in Ontario: Gender, Islam, and Representations of Muslim Women's Agency. Gender \& Society 22: 434454.

Korteweg AC and Selby JA. (2012) Debating Sharia: Islam, Gender Politics, and Family Law Arbitration. Toronto: University of Toronto Press.

Kuru AT. (2009) Secularism and State Policies Toward Religion: The United States, France, and Turkey, Cambridge and New York: Cambridge University Press. 
Lacey N. (2003) Institutionalising Responsibility: Implications for Jurisprudence. Jurisprudence 4: 1-19.

Laird K. (2014) Confronting Religion: Veiled Witnesses, the Right to a Fair Trial and the Supreme Court of Canada's Judgment in R v N.S. Modern Law Review 77: 123-138.

Latour B. (2010) The Making of Law: An Ethnography of the Conseil d'Etat, Cambridge, UK ; Malden, MA: Polity Press.

Modood T. (2012) Is There a Crisis of Secularism in Western Europe? Sociology of Religion 73: 130-149.

Moon R. (2014) Freedom of Conscience and Religion, Toronto: Irwin Law.

Moore SF. (1978) Law as Process: An Anthropological Approach, London; Boston: Routledge \& K. Paul.

National Post. (2011) Niqabs, burkas must be removed during citizenship ceremoies: Jason Kenney. The National Post.

Razak S. (2007) The 'Sharia Law Debate' in Ontario: The Modernity/Premodernity Distinction in Legal Efforts to Protect Women from Culture. Feminist Legal Studies 15: 3-32.

Scott JW. (2007) The Politics of the Veil, Princeton, N.J.: Princeton University Press.

Seligman A, Weller RP, Puett MJ, et al. (2008) Ritual and its Consequences: An Essay on the Limits of Sincerity, Oxford; New York: Oxford University Press.

Taylor C. (2007) A Secular Age, Cambridge and London: Harvard University Press.

Warner M, VanAntwerpen J and Calhoun C. (2010) Varieties of Secularism in a Secular Age. Cambridge and London: Harvard University Press.

Webber J. (1994) Reimagining Canada: language, culture, community and the Canadian constitution, Montreal: McGill-Queen's University Press.

Whitman JQ. (2008) Separating Church and State: The Atlantic Divide. Historical Reflections 34: 86. 